\title{
Experimental-Phonetic Analysis of Suprasentential Units in the English Language
}

\author{
Lala Gadir Gurbanova ${ }^{1}$ \\ ${ }^{1}$ The Institute of Linguistics, Azerbaijan National Academy of Sciences, Baku, Azerbaijan \\ Correspondence: Lala Gadir Gurbanova, Department of English Grammar, Azerbaijan University of Languages, \\ Baku, Azerbaijan, AZ1014. 134, Rashid Behbudov str. E-mail: lala.qedirova@mail.ru
}

Received: February 5, 2020 Accepted: March 20, 2020 Online Published: April 6, 2020

doi:10.5539/ijel.v10n3p229 URL: https://doi.org/10.5539/ijel.v10n3p229

\begin{abstract}
The current article deals mainly with the suprasentential units in English and their characteristic peculiarities. Some viewpoints of western, Russian and Azerbaijani linguists are discussed here. One of the important matters discussed here is to distinguish the notions "text" and "suprasentential units", which was possible owing to the viewpoints and investigations of specialists in this field. To determine "suprasentential units", some other terms such as, "micro-text" and "macro-text" are discussed here, too.

To get a detailed information on "suprasentential units", phonetic experiment was carried out. The essence of the article is to determine the phoneticparameters of "suprasentential units" in the form of a short text. The experiment was realised at the Institute of Linguistics of the National Academy of Sciences of Azerbaijan. For acoustic analysis of the recorded materials, "Speech Analyser", "WinCecil", "PRAAT", "MacSpeech Lab" programs have been used. In the acoustic analysis of speech signals of the given short text, the valuable "PRAAT" computer program created by the professors of Amsterdam University Paul Boersman and David Veenik has been widely used. "PRAAT" computer program has wide opportunities, such as to hold ossillographic and spectographic analysis of language materials (in our case, short texts), to get indicators of tonal frequency intensity, and length of language materials, etc. The above mentioned computer program provides specialists and learners with the chance of learning speech fragments having the recording time from several $\mathrm{m} / \mathrm{sec}$ to several hours.
\end{abstract}

Keywords: syntagm, sentence, suprasentential units, experiment, text, phonetic analysis, parameters

\section{Introduction}

The text is connected with the determination of its structural units (or unit) which is one of the important issues of linguistics.

Linguistic analysis of the text is mainly carried out in two directions. The first one focuses on the description of functional-meaning types as the structural unit of speech, and the second one focuses on the classification and description of complex syntactic whole. Here, it is typical to apply the category and notions of sentence syntax on the suprasentential units.

The text is accepted as the main communication unit. However, the communication process like the transmission and perception of information is not possible without dividing into relative complete units (quantums), otherwise the information exchange would have lost its essence. As Abdullayev notes, "the text is such a syntactic complex that it removes a relatively incompleteness, certain semantic defects of another syntactic complex, that is, a sentence from the point of view of its meaning. Thus, the text itself demonstrates a completeness of meaning. ... the text acts as a key factor in the process of obtaining semantic information by the recipient" (Abdullayev, 1999) or " ... the information is presented in the text, not wholly in the sentence. It is precisely the unity of sentences that can become an information shelter that is the basis for speech activities" (Abdullayev, 1999).

According to Veysalli, “... text is one of the main units of communication in language. At first glance, it is possible to define text as a sequence of sentences. Text is the driving force of the sentence. Among the factors contributing to the formation of internal relationships of the text, grammatical and phonetic means, as well as intonation, play an important role" (Veysalli, 2013).

As the main units of the text, a suprasentential unit, a complex syntactic whole, a paragraph, predicative-relative 
complexes are offered. The hierarchy of text units also includes a syntagma, which is accepted as a universal unit (Scherba, 1974). Researchers suggest either a suprasentential unit or an utterance as a main unit of the voice text. In textology, a suprasentential unit, which is understood as a complex structural whole, consisting of one or two sentences, having the completeness of meaning in a connected speech and acting as a part of complete communication, is considered a constituent of a text.

It should be noted that Pospelov paid a special attention to the study of speech units which opposed language units (sentences). According to the author, "when studying the syntactic structure of speech, the sentence cannot be the first unit, because it is deprived of independence in the connected text and it is only in close contact with other sentences" (Pospelov, 1948). According to Pospelov, "the sequences of sentences that serve to express complex ideas and that are interrelated among themselves, have relative independence in the context. Obviously, the completeness of a thought within a suprasentential unit should be understood as a relative expression. The suprasentential unit, as a single sentence, is semantically related to both previous and next texts, but differs from a single sentence for its possession of a row of unlimited sentences. It is able to express to the listener (reader), the appropriate structures without necessity to increase the number of sentences, periods, subordinate clauses and parenthetical elements (sentences), in order to the quicker understanding of their thoughts" (Pospelov, 1948).

\section{Methodology}

As a material of the investigation, some English literary works, newspaper materials, radio and TV-programs in English and Azerbaijani (Az.Lider TV and BBC TV)) have been used. In the investigation complex semantic-intonation analysis has been used. This method analyses the given material from the listening, auditive, electro-acoustic points of view. Besides, comparative and mathematical-statistical analysis methods are also used to investigate and achieve necessary results. The third set of methods used to analyse the suprasentential units include descriptive analysis and contextual analysis of language units.

To get acoustic analysis of the recorded materials, "Speech Analyser", "WinCecil", "PRAAT", "MacSpeech Lab" programs have been used. In the acoustic analysis of speech signals "PRAAT" computer program, which has been created by the professors of Amsterdam University Paul Boersman and David Veenik to hold special experiments, has been widely used. "PRAAT" computer program has wide opportunities, such as to hold ossillographic and spectographic analysis of language materials, to get indicators of tonal frequency intensity, and length of language materials, etc. The given computer program provides learners with the chance of learning speech fragments which have the recording time from several $\mathrm{m} / \mathrm{sec}$ to 12 hours.

\section{Discussions}

\subsection{Characteristics of Suprasentential Units}

The reasoning of the suprasentential units in the quality of the minimal unit of the text is clarified when considering it in comparison with the sentence. The sentence is only considered as the constituent of suprasentential units. The sentence, which is a relatively large section of the utterance, cannot be an integral part of the whole which joins those sections at the same time. There are certain regularities that raise the sections that are bigger than a sentence to the level of language units. Therefore, special status is applied to suprasentential units.

Bulakhovskiy offers the term "suprasentential unit" "where syntactic indicators exist" for expressions with particular words (Bulakhovskiy, 1952). In his opinion, it is important for complex syntactic wholes to have meaning(s) connectors (pronouns), conjunctions, parenthetical words (elements). In addition, the author links elements of suprasentential units with rhythmic-melodic groups (Bulakhovskiy, 1952). According to him, "in writing, their outer means of expression is a new line separating one whole from another one" (Brizgunova, 1993).

In his article "Discourse Analysis", Haris speaks not of sentences, but of upper sentence units, which are bigger than a sentence. Levis explains suprasentential units like this: "The suprasentential lexical union (unit) is very important in order to reveal the meaning (cohesion) in a spontaneous speech, and the demanded units, having a structured structure, are the unity of sentences with a pragmatic effect and very natural sentence" (James, 1947).

Masalan, II gave the rice to mother. She divided the rice into two, and went out, carrying half the rice. When she came back, I asked her, to my neighbours- they are hungry also!

II was not surprised that she gave,because poor people are really very, generous// (Mon onun vermasina taวccüblanma- dim, çünki kasıb insanlar haqiqatən aliaçıq olur); /But I was surprised that $\mid$ she knew they were hungry// (Amma man taxccüblandim ki, o onlarn ac olduğunu bilir); //As a,rule,| when we are,suffering,|we are so focused on ourselves we have no time for others// (Adatan, biz aziyyat çəkəndə, bizim fikrimiz özümüz bağlandığından başqaları üçün vaxt olmur) (Mother Teresa: To my neighbour). 
It is evident from the quote that to distinguish a suprasentential unit, there must be a single microtheme, the semantic commonness of sentences, the semantic solidarity of sentences, the semantic and communicative unity of sentences. This also denotes that discreteness conditions completeness and independence as a criterion for suprasentential units.

The suprasentential unit is a special syntactic-stylistic unit represented in the form of close interaction of two or more sentences, which are united around a common microtheme. The dependence of the text is provided by the interrelation of the elements that make up the sentence, and within the boundaries of suprasentential units, the interrelation of sentences and the interconnection of the letters can be not only from semantic viewpoint, but also from formal point of view. The formal interconnection of suprasentential units, which create a text, is realized by lexical and grammatical means. Every suprasentential unit has a theme-rheme progression according to the theme-rheme parsing of the sentences included in it.

According to Referovskaya, a suprasentential unit, which is bigger than a sentence and is a component of larger textual units, and ultimately a unit of a text, can be viewed from three points of view: 1) its formal-linguistic structure, and the possibilities of finding out different types of suprasentential units; 2) the nature of lexical and grammatical interconnections that combine sentences into a larger language unit; 3) communicative assignments that they carry out, that is, providing a certain information (Reformatskiy, 1955).

Determination of the theme-rheme relations between sentences within a suprasentential units allows You to trace all the details of building a text, the relations between the theme and the rheme. Moskalskaya offers to use the terms "macro-" and "microtext" to distinguish the essence of the text. The author understands microtext as "a suprasentential unit (a compound syntactic unit) - in a narrow meaning of the word" a text" (Moskalskaya, 1981). Moskalskaya uses three terms - suprasentential unit, compound syntactic whole and microtext - to express the complex utterance arising in the speech process. According to the author, out of the terms singled out, the most common one is the "suprasentential unit": "Suprasentential unit" (microtext), at the same time, is a syntagmatic and a functional notion. It is a specially organized and a closed chain of sentences that, in itself, represent a single utterance" (Moskalskaya, 1981).

According to Moskalskaya, who refers to the content and formal integrity of suprasentential units and points out that "the intertransition of themes and, consequently, the breaking of the thematic progression serves as interchangeable signals between the suprasentential units" (Nikolayeva, 1969).

There are different types of subdivisions defined by 1) the type of sentences included in the whole, and 2) the nature of the relationship between them. These factors may depend on the functional style and the genre's possession of the text and the author's individual style.

Mammadov characterizes the complex syntactic whole as "sentence combinations that combine specific syntactic relationships with the commonness of meaning, relatively regardless of the context" (Mammadov, 2003). According to the author, "together with the meaning characteristic to supraphrasal units, ... they also distinguish the structural, syntactic characteristics, and, first of all, the existence of connections between the sentence components of a complex syntactic whole. Obviously, on this basis, they define syntactic units as complex syntactic wholes" (Mammadov, 2003).

Some linguists consider paragraphs to be the same with suprasentential units and define them as the minimal unit of text parsing. For example, when Peshkovskiy, says paragraphs, he implies "a unity of a complex whole from one red line to another" (Pierce, 2000). Peshkovskiy, who doesn't consider a paragraph to be the same with a suprasentential unit, adds that "the interval between paragraphs is relatively longer than that, which separates suprasentential units" (Pierce, 2000). However, it is difficult to agree fully with this approach, because suprasentential unit can sometimes combine several paragraphs. However, Pospelov, who investigates this issue, tries to interpret the paragraph as a composition unit of a "text" (Potapova, 1981). Speaking about the peculiarity of the paragraph, Gvozdev included it in punctuation marks for its function (Glison, 1959).

The main difference between the suprasentential unit and the paragraph is that the suprasentential unit can consist of the utterance creating an entirely objective limited microtheme. However, in spite of the occasional deviations from the main theme in suprasentential unit, there are cases to end it by returning to the breaking point again. The fact that the paragraph covers the finished microtheme spread to neighboring paragraphs is not an absolute issue. As a result, a word, a microtheme, as a rule, is always one suprasentential unit, but a whole suprasentential unit may contain one, two or more paragraphs. This means that it is not an absolute matter to have overlapping boundaries of the paragraph and the suprasentential unit. They only coincide when the objective parsing of the text corresponds to the subjective attitude of the text that the author just created, or when the author emphasizes this or any other detail particularly, or, vice-versa, when he wants to join two or more utterances, of them and each of has 
a certain meaning in one whole.

Pospelov, who tried first to study fundamentally the complex syntactic whole in Soviet linguistics, has also done a research to identify its features, too. Among the features of complex syntactic whole, the author notes the followings: closed syntactic structure, syntactic independence in the context, intermittent nature of the sentences in a complex syntactic whole, heterogenous character of the composition of the complex syntactic whole, etc. (Potapova, 1981).

In general, suprasentential unit can be defined as a relatively independent unit of the text from the structural-semantic and syntactic-thematic point of view. The idea that the suprasentential unit has constitutive features has always been in the focus of text linguistics. For example, according Friedman, "we cannot talk about the structure of a whole text, but we can deal with the structure of its sections. The whole text is nothing except the totality of its structured sections" (Cheremisina, 1989).

In a language, a suprasentential unit contains information about a single situation and names it. The suprasentential unit in the semantic plan expands and develops "lexical inheritance", the breadth of the content of the subject, until its disclosure (each following member of the complex syntactic whole broadens and develops the contents of the preceding member) (Vall et al., 1984).

For example, /Bu yerlardə axşama yaxın hava soyuq və rütubətli olur. Kənddən gələn səslər, darvazaların cırıltısı qeyri-adi daracada aydin eşidilir. Qaranlıq düşür. Bağdan yanan ocaqdan gilas ăgacının budaqlarının atirli tüstüsü ətrafa yayılır. Qaranlıqda, bağın dərinliyində nağıllardakı kimi mənzərə komanın yanında zülmətla shatว olunmuş ocaqda alovun tünd qırmızı dillari şölənənir, bir qədər aralıda isə kiminsa silueti hərəkət edir, onun nəhəng qara kölgasi isə alma ağaclarının üzərində əks olunur//.

In these places, the weather becomes cold and humid in the evening. The sounds coming from the village, the roar of gates are heard extraordinarily clearly. It's getting dark. The smell of cherry tree branches spreads around from the burning garden fire. In the dark, in the depths of the garden, the scenery as in fairy tales, in the fireplace surrounded by the darkness near the inn, the dark red flames of the fire are shining, and at a distance someone's silhouette is moving, its giant black shadow is reflected on the apple trees//.

In the given example, the suprasentential unit consists of four sentences combined around the description of the night garden.

\subsection{Material Selection for the Phonetic Experiment}

In order to carry out the experimental-phonetic analysis of the suprasentential units in English (based on the English materials), 15 small texts were selected from the English sources. This article presents an experimental-phonetic

analysis of only one of those texts. This is the text of "The shops".

\section{The shops}

Today the women are going to Oxford Street to shop.

Both of the girls and my wife are going.

They don't want Simon and me with them.

Thank goodness!

Women are terrible shoppers.

They spend a lot of time and they only buy a few things.

I only spend a little time and I buy a lot of things.

Sometimes my wife shops all day and she doesn't buy anything.

She tries on clothes all day and then doesn't bring anything home.

This seems mad!

She's too fussy.

She only likes a few colours.

She only likes blue, green and yellow.

Her favourite colour is either blue or green.

I don't know which one. 
She doesn't like red and pink.

They're too bright.

They don't suit her.

And brown and grey aren't bright enough.

Oh, she's fussy!

\subsection{Experimental-Phonetic Analysis of the Selected Text}

The English text/ðə ' $\int \mathbf{p p s} / /($ Theshops) deals with shopping on Oxford Street.

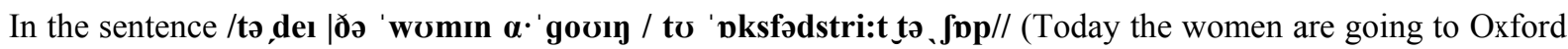
Street to shop.) two syntagmas are realized.

Syntagma I - /to , deı ðə 'womın $\boldsymbol{\alpha} \cdot$ ' gooı /

Syntagma II - /to' 'pksfod stri:t to 、 Jpp//

The acoustic parameters in the progredient syntagm are expressed by the following figures:

Main tone frequency: $\mathrm{V}_{1} \mathrm{f}-125 \mathrm{hs}, \mathrm{V}_{2} \mathrm{f}-205 \mathrm{hs}, \mathrm{V}_{3} \mathrm{f}-152 \mathrm{hs}, \mathrm{V}_{4} \mathrm{f}-131 \mathrm{hs}, \mathrm{V}_{5} \mathrm{f}-151 \mathrm{hs}, \mathrm{V}_{6} \mathrm{f}-157 \mathrm{hs}, \mathrm{V}_{7} \mathrm{f}-148$ hs, $\mathrm{V}_{8} \mathrm{f}-123 \mathrm{hs}$;

Intensity parameter: $\mathrm{V}_{1} \mathrm{i}-74 \mathrm{db}, \mathrm{V}_{2} \mathrm{f}-86 \mathrm{db}, \mathrm{V}_{3} \mathrm{f}-83, \mathrm{~V}_{4} \mathrm{f}-82, \mathrm{~V}_{5} \mathrm{i}-79 \mathrm{db}, \mathrm{V}_{6} \mathrm{i}-78 \mathrm{db}, \mathrm{V}_{7} \mathrm{i}-78 \mathrm{db}, \mathrm{V}_{8} \mathrm{i}-73 \mathrm{db}$;

Temporal parameter: $\mathrm{V}_{1} \mathrm{t}-76 \mathrm{~m} / \mathrm{sec}, \mathrm{V}_{2} \mathrm{t}-208 \mathrm{~m} / \mathrm{sec}, \mathrm{V}_{3} \mathrm{t}-96 \mathrm{~m} / \mathrm{sec}, \mathrm{V}_{4} \mathrm{t}-72 \mathrm{~m} / \mathrm{sec}, \mathrm{V}_{5} \mathrm{t}-81 \mathrm{~m} / \mathrm{sec}, \mathrm{V}_{6} \mathrm{t}-97$ $\mathrm{m} / \mathrm{sec}, \mathrm{V}_{7} \mathrm{t}-146 \mathrm{~m} / \mathrm{sec}, \mathrm{V}_{8} \mathrm{t}-72 \mathrm{~m} / \mathrm{sec}$.

In the terminal syntagma /to ' $\mathbf{p k s f a d s t r i : t ~ t o ~} \int \mathbf{p p} / /$ the parameters are as follows:

Main tone frequency: $\mathrm{V}_{1} \mathrm{f}-152 \mathrm{hs}, \mathrm{V}_{2} \mathrm{f}-136 \mathrm{hs}, \mathrm{V}_{3} \mathrm{f}-140 \mathrm{hs}, \mathrm{V}_{4} \mathrm{f}-147 \mathrm{hs}, \mathrm{V}_{5} \mathrm{f}-142 \mathrm{hs}, \mathrm{V}_{6} \mathrm{f}-130 \mathrm{hs}$; Intensity parameter: $\mathrm{V}_{1} \mathrm{i}-68 \mathrm{db}, \mathrm{V}_{2} \mathrm{f}-74 \mathrm{db}, \mathrm{V}_{3} \mathrm{f}-73 \mathrm{db}, \mathrm{V}_{4} \mathrm{f}-65 \mathrm{db}, \mathrm{V}_{5} \mathrm{i}-62 \mathrm{db}, \mathrm{V}_{6} \mathrm{i}-69 \mathrm{db}$;

Temporal parameter: $\mathrm{V}_{1} \mathrm{t}-84 \mathrm{~m} / \mathrm{sec}, \mathrm{V}_{2} \mathrm{t}-76 \mathrm{~m} / \mathrm{sec}, \mathrm{V}_{3} \mathrm{t}-70 \mathrm{~m} / \mathrm{sec}, \mathrm{V}_{4} \mathrm{t}-86 \mathrm{~m} / \mathrm{sec}, \mathrm{V}_{5} \mathrm{t}-70 \mathrm{~m} / \mathrm{sec}, \mathrm{V}_{6} \mathrm{t}-86$ $\mathrm{m} / \mathrm{sec}$.

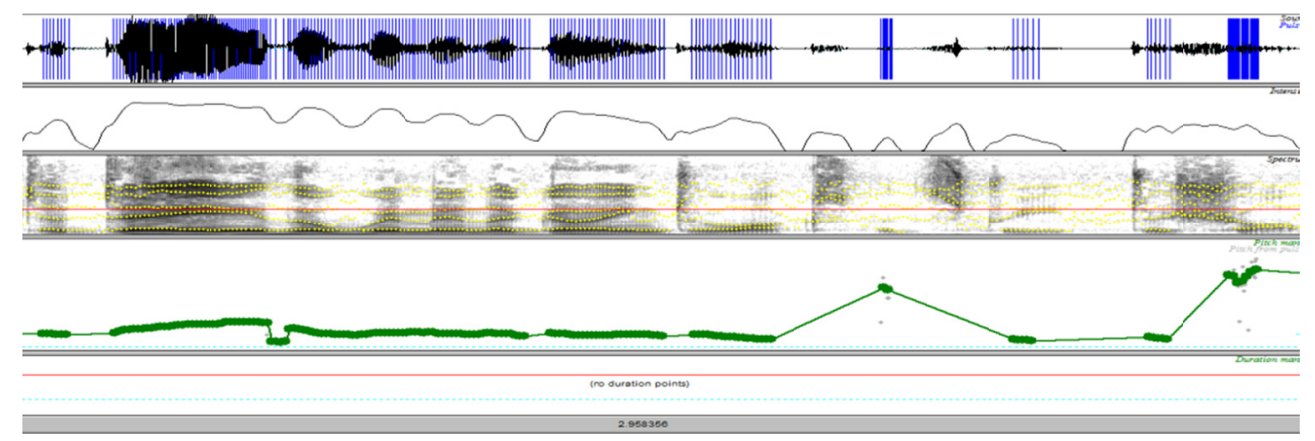

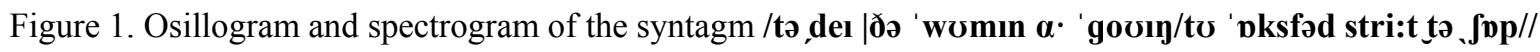

\section{/to , del | Øә 'wımın $\alpha \cdot$ ' gooly / to 'pksfodstri:t to , Jpp//}

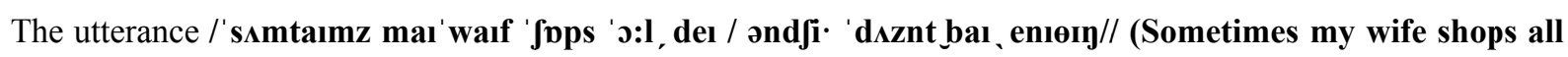
day and she doesn't buy anything), which is realized in the middle, consists of two syntagms.

The acoustic parameters in the progredient syntagm are expressed by the following figures:

Main tone frequency: $\mathrm{V}_{1} \mathrm{f}-217 \mathrm{hs}, \mathrm{V}_{2} \mathrm{f}-181 \mathrm{hs}, \mathrm{V}_{3} \mathrm{f}-165 \mathrm{hs}, \mathrm{V}_{4} \mathrm{f}-168 \mathrm{hs}, \mathrm{V}_{5} \mathrm{f}-146 \mathrm{hs}, \mathrm{V}_{6} \mathrm{f}-208 \mathrm{hs}, \mathrm{V}_{7} \mathrm{f}-122$ hs;

Intensity parameter: $\mathrm{V}_{1} \mathrm{i}-86 \mathrm{db}, \mathrm{V}_{2} \mathrm{f}-82 \mathrm{db}, \mathrm{V}_{3} \mathrm{f}-79 \mathrm{db}, \mathrm{V}_{4} \mathrm{f}-82, \mathrm{~V}_{5} \mathrm{i}-81 \mathrm{db}, \mathrm{V}_{6} \mathrm{i}-85 \mathrm{db}, \mathrm{V}_{7} \mathrm{i}-62 \mathrm{db}$;

Temporal parameter: $\mathrm{V}_{1} \mathrm{t}-106 \mathrm{~m} / \mathrm{sec}, \mathrm{V}_{2} \mathrm{t}-199 \mathrm{~m} / \mathrm{sec}, \mathrm{V}_{3} \mathrm{t}-148 \mathrm{~m} / \mathrm{sec}, \mathrm{V}_{4} \mathrm{t}-138 \mathrm{~m} / \mathrm{sec}, \mathrm{V}_{5} \mathrm{t}-93 \mathrm{~m} / \mathrm{sec}, \mathrm{V}_{6} \mathrm{t}-$ $100 \mathrm{~m} / \mathrm{sec}, \mathrm{V}_{7} \mathrm{t}-260 \mathrm{~m} / \mathrm{sec}$.

The acoustic parameters in the terminal syntagma /ond fi $\cdot$ 'dsznt bar, enıөry//are performed in the following sequence: 
Main tone frequency: $\mathrm{V}_{1} \mathrm{f}-136 \mathrm{hs}, \mathrm{V}_{2} \mathrm{f}-140 \mathrm{hs}, \mathrm{V}_{3} \mathrm{f}-153 \mathrm{hs}, \mathrm{V}_{4} \mathrm{f}-142 \mathrm{hs}, \mathrm{V}_{5} \mathrm{f}-137 \mathrm{hs} \mathrm{V}_{6} \mathrm{f}-128 \mathrm{hs} \mathrm{V}_{7} \mathrm{f}-116 \mathrm{hs}$; Intensity parameter: $\mathrm{V}_{1} \mathrm{i}-67 \mathrm{db}, \mathrm{V}_{2} \mathrm{f}-75 \mathrm{db}, \mathrm{V}_{3} \mathrm{f}-82, \mathrm{~V}_{4} \mathrm{f}-81 \mathrm{db}, \mathrm{V}_{5} \mathrm{f}-78 \mathrm{db} ; \mathrm{V}_{6} \mathrm{f}-73 \mathrm{db} ; \mathrm{V}_{7} \mathrm{f}-64 \mathrm{db}$;

Temporal parameter: $\mathrm{V}_{1} \mathrm{t}-70 \mathrm{~m} / \mathrm{sec}, \mathrm{V}_{2} \mathrm{t}-67 \mathrm{~m} / \mathrm{sec}, \mathrm{V}_{3} \mathrm{t}-92 \mathrm{~m} / \mathrm{sec}, \mathrm{V}_{4} \mathrm{t}-172 \mathrm{~m} / \mathrm{sec}, \mathrm{V}_{5} \mathrm{t}-82 \mathrm{~m} / \mathrm{sec}, \mathrm{V}_{6} \mathrm{t}-78$ $\mathrm{m} / \mathrm{sec}, \mathrm{V}_{7} \mathrm{t}-73 \mathrm{~m} / \mathrm{sec}$.

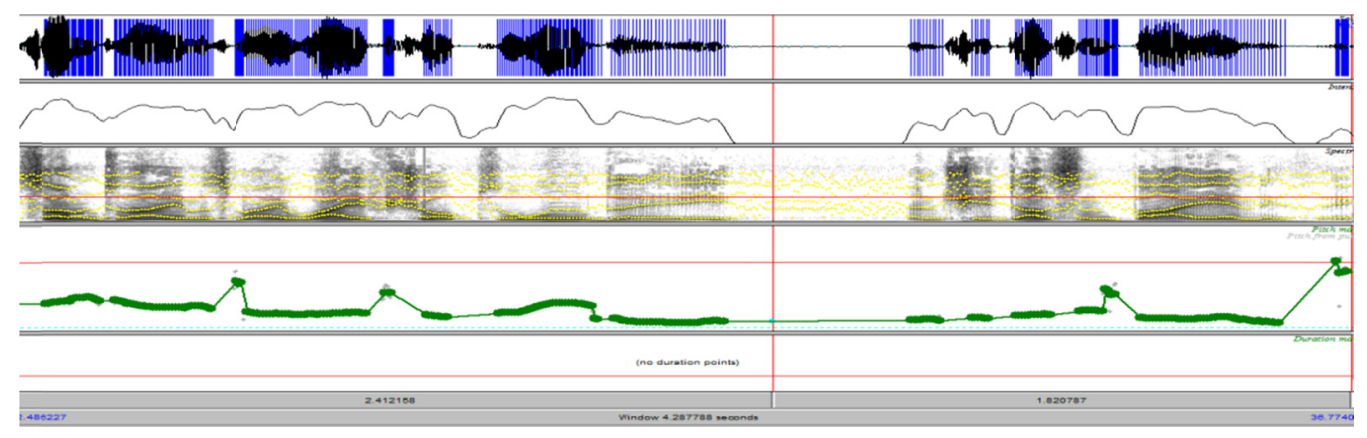

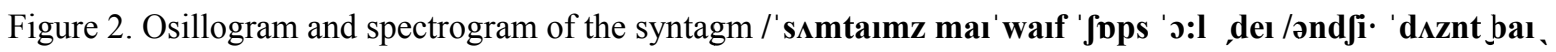
enırg//

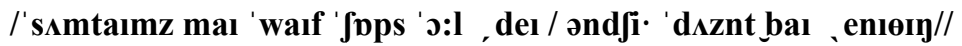

The last utterance of the analysed text is /and 'broonond, gre / $/ \boldsymbol{\alpha}: \mathbf{n t} \_$braitı n $\mathbf{n} \mathbf{f} \mid / /$ consists of two syntagms. The acoustic parameters in the progredient syntagm are expressed by the following figures:

Main tone frequency: $\mathrm{V}_{1} \mathrm{f}-133 \mathrm{hs}, \mathrm{V}_{2} \mathrm{f}-186 \mathrm{hs}, \mathrm{V}_{3} \mathrm{f}-142 \mathrm{hs}, \mathrm{V}_{4} \mathrm{f}-147 \mathrm{hs}$;

Intensity parameter: $\mathrm{V}_{1} \mathrm{i}-86 \mathrm{db}, \mathrm{V}_{2} \mathrm{f}-84 \mathrm{db}, \mathrm{V}_{3} \mathrm{f}-74 \mathrm{db}, \mathrm{V}_{4} \mathrm{f}-76 \mathrm{db}$;

Temporal parameter: $\mathrm{V}_{1} \mathrm{t}-78 \mathrm{~m} / \mathrm{sec}, \mathrm{V}_{2} \mathrm{t}-223 \mathrm{~m} / \mathrm{sec}, \mathrm{V}_{3} \mathrm{t}-86 \mathrm{~m} / \mathrm{sec}, \mathrm{V}_{4} \mathrm{t}-206 \mathrm{~m} / \mathrm{sec}$.

The acoustic parameters in the terminal syntagma /ond $\mathbf{j i} \cdot{ }^{\prime} \mathbf{d} \mathbf{A z n t} \mathbf{b a r}$, enıөı//are performed in the following sequence:

Main tone frequency: $\mathrm{V}_{1} \mathrm{f}-169 \mathrm{hs}, \mathrm{V}_{2} \mathrm{f}-153 \mathrm{hs}, \mathrm{V}_{3} \mathrm{f}-147 \mathrm{hs}, \mathrm{V}_{4} \mathrm{f}-151 \mathrm{hs}$;

Intensity parameter: $\mathrm{V}_{1} \mathrm{i}-77 \mathrm{db}, \mathrm{V}_{2} \mathrm{f}-76 \mathrm{db}, \mathrm{V}_{3} \mathrm{f}-73 \mathrm{db}, \mathrm{V}_{4} \mathrm{f}-70 \mathrm{db}$;

Temporal parameter: $\mathrm{V}_{1} \mathrm{t}-113 \mathrm{~m} / \mathrm{sec}, \mathrm{V}_{2} \mathrm{t}-162 \mathrm{~m} / \mathrm{sec}, \mathrm{V}_{3} \mathrm{t}-101 \mathrm{~m} / \mathrm{sec}, \mathrm{V}_{4} \mathrm{t}-113 \mathrm{~m} / \mathrm{sec}$.

In the last sentence of the analyzed text $-/$ oo $\mid \mathbf{f i} \cdot \mathbf{z} \quad \mathbf{f}_{\mathbf{\Lambda}} \mathbf{S I} / /(\mathbf{O h}, \mathbf{s h e} \mathbf{s}$ fussy!) acoustic parameters are represented by the following figures:

Main tone frequency: $\mathrm{V}_{1} \mathrm{f}-183 \mathrm{hs}, \mathrm{V}_{2} \mathrm{f}-132 \mathrm{hs}, \mathrm{V}_{3} \mathrm{f}-147 \mathrm{hs}, \mathrm{V}_{4} \mathrm{f}-121 \mathrm{hs}$;

Intensity parameter: $\mathrm{V}_{1} \mathrm{i}-84 \mathrm{db}, \mathrm{V}_{2} \mathrm{f}-61 \mathrm{db}, \mathrm{V}_{3} \mathrm{f}-71 \mathrm{db}, \mathrm{V}_{4} \mathrm{f}-63 \mathrm{db}$;

Temporal parameter: $\mathrm{V}_{1} \mathrm{t}-232 \mathrm{~m} / \mathrm{sec}, \mathrm{V}_{2} \mathrm{t}-63 \mathrm{~m} / \mathrm{sec}, \mathrm{V}_{3} \mathrm{t}-89 \mathrm{~m} / \mathrm{sec}, \mathrm{V}_{4} \mathrm{t}-76 \mathrm{~m} / \mathrm{sec}$.

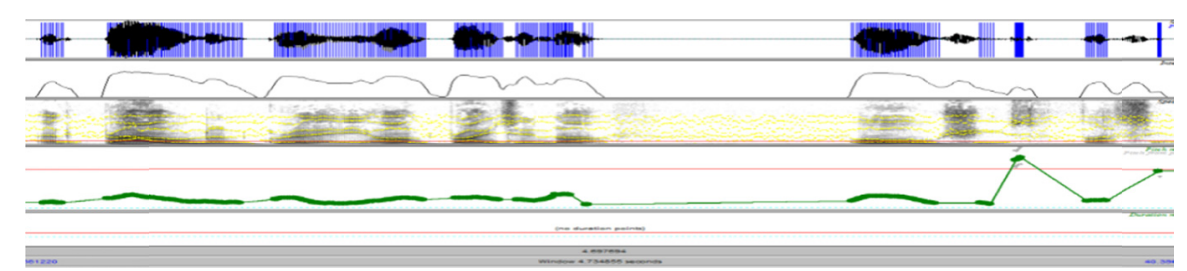

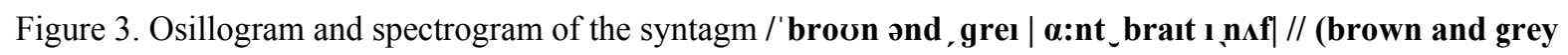
aren't bright enough) ; / oo $\mid \mathbf{f i} \cdot \mathbf{z}, \mathbf{f} \Lambda \mathrm{si} / /(\mathrm{Oh}$, she's fussy!)

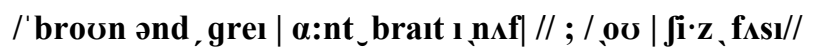


Table 1. Indicators of the acoustic parameters of the sentence on the syntagms

\begin{tabular}{|c|c|c|c|c|c|c|c|c|c|c|c|c|c|c|c|}
\hline syllables & acoustic settings & 1 & 2 & 3 & 4 & 5 & 6 & 7 & 8 & 9 & 10 & 11 & 12 & 13 & 14 \\
\hline \multirow[t]{3}{*}{ Utterance I } & $\begin{array}{l}\text { Main tone } \\
\text { frequency }(\mathrm{hs})\end{array}$ & 125 & 205 & 152 & 131 & 151 & 157 & 148 & 123 & 152 & 136 & 140 & 147 & 142 & 130 \\
\hline & Intensity (db) & 74 & 86 & 83 & 82 & 79 & 78 & 78 & 73 & 68 & 74 & 73 & 65 & 62 & 69 \\
\hline & Time (t) & 76 & 208 & 96 & 72 & 81 & 97 & 146 & 72 & 84 & 76 & 70 & 86 & 70 & 86 \\
\hline \multirow[t]{3}{*}{ Utterance II } & $\begin{array}{l}\text { Main tone } \\
\text { frequency }(\mathrm{hs})\end{array}$ & 217 & 181 & 165 & 168 & 146 & 208 & 122 & 136 & 140 & 153 & 142 & 137 & 128 & 116 \\
\hline & Intensity (db) & 86 & 82 & 79 & 82 & 81 & 85 & 62 & 67 & 75 & 82 & 81 & 78 & 73 & 64 \\
\hline & Time (t) & 106 & 199 & 148 & 138 & 93 & 100 & 260 & 70 & 67 & 92 & 172 & 82 & 78 & 73 \\
\hline \multirow[t]{3}{*}{ Utterance III } & $\begin{array}{l}\text { Main tone } \\
\text { frequency }(\mathrm{hs})\end{array}$ & 133 & 186 & 142 & 147 & 169 & 153 & 147 & 151 & & & & & & \\
\hline & Intensity (db) & 86 & 84 & 74 & 76 & 77 & 76 & 73 & 70 & & & & & & \\
\hline & Time $(\mathrm{t})$ & 78 & 223 & 86 & 206 & 113 & 162 & 101 & 113 & & & & & & \\
\hline \multirow[t]{3}{*}{ Utterance IV } & $\begin{array}{l}\text { Main tone } \\
\text { frequency (hs) }\end{array}$ & 183 & 132 & 147 & 121 & & & & & & & & & & \\
\hline & Intensity (db) & 84 & 61 & 71 & 63 & & & & & & & & & & \\
\hline & Time (t) & 232 & 63 & 89 & 76 & & & & & & & & & & \\
\hline
\end{tabular}

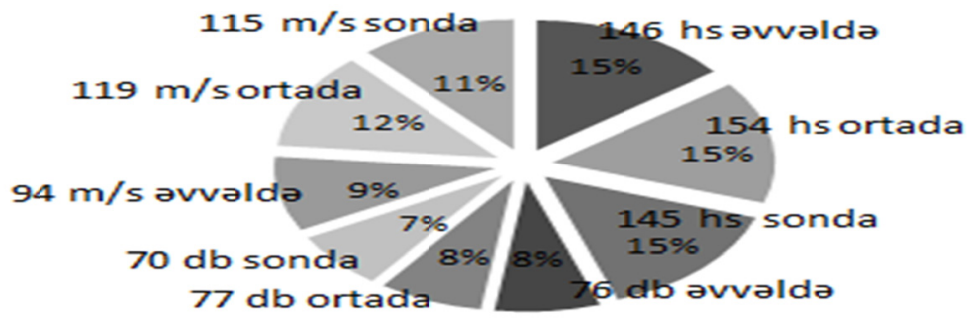

Figure 4. The average Acoustic Indicators of the text on syntagms (\%)

Note. sonda - at the end, əvvəldə - at the beginning, ortada - in the middle.

\section{Results: Linguistic Interpretation of the Phonetic Experiment Results}

We should note that the matter of function of intonation in English and other phonetic literature is debatable (Zinder, 1979; Nikolayeva, 1977; Bloxina, 1980; Bondarko, 1982; Svetozarova, 1982; Torsuyeva, 1984; Veyselli, 2014; Zlatoustova, 1997; Gordina, 1997; Potapova, 2003). For example, Zinder points out that numerous meanings of intonation are considered as a special function, but shows that this approach is wrong: "It is very difficult to calculate the number of such meanings and to formulate their essence in a widely accepted degree" (Zinder, 1981).

The study of functions of intonation in two aspects - the parsing of speech act and its organization from semantic point of view, and its relation to the expression of subjective attitudes - is characteristic to the creative activity of the researchers like Sherba (1963), Bondarko (1981, 1987), Svetozarova (1982), Nikolayeva (1977), Zinder (1979), Brizgunova (1963, 1978), Torsuyeva (1984), Veyselli (2014), Gordina (1997).

The study of the expression of emotion through intonation is also reflected in Scherba's creative activity: "We can express various effects of the conversation in the most subtle ways: hatred, anger, indifference, irony, displeasure, elegance, distrust, anxiety and so on" (Scherba, 1974).

The expression of emotions, psychological state, intentions of the speaker and so on is an integral component of communication. It is the intonation that is directly related to the subjective attitude of the speaker-emotions, expression, criticism and different assessment acts.

We would like to add that the emotional function of intonation can be referred to its communicative function, as communication means transmission of information by a language or other sign systems. Thus, the emotional function of intonation is to provide information about the speaker's emotional state, his or her attitude to evaluating of the object. 
Zinder, taking into consideration this, notes that "every communication act reflects not only what is being talked about (denotative aspect), but also the attitude of the speaker (the connotative aspect) to the information" (Zinder \& Stroley, 1957). According to the author, "Removal of emotion from the research object cannot be justified" (Zinder \& Stroley, 1957).

Commenting on the function of intonation, Zinder provides information by its two main functions (Zinder \& Stroley, 1957) - communicative "whether intonation utterance is completed or not, its (note - by L.G.) consisting of a question, answer and so on" (Zinder \& Stroley, 1957), and emotional "a certain emotion that reflects the emotional state of speaker in intonation, takes place" (Zinder \& Stroley, 1957).

Within the general communicative function of intonation, Zinder defines the following meanings:

1) intonation is a tool for division of speech into the sentences (utterances), and sentences into syntagms;

2) intonation participates in differentiating communicative types of sentences;

3) intonation is a means of actual parsing of a sentence;

4) parsing into syntagms defined by meaning is accomplished only through intonation and is associated with this or another member of the sentence;

5) intonation signifies the terminal and initial sintagm of a particular speech section (Zinder \& Stroley, 1957).

As we have mentioned, the main procedural means of speech are the frequency, length, and intensity of the main tone. The most universal of the prosodic means is the frequency of the main tone, as "all kinds of intonation information can be transmitted by the modification of the main tone frequency" (Zolotova, 1984).

In addition, the main tone frequency is considered dominant among prosodic means and in the interpretation of the information. In study the intonation structure of the utterance, Golovin notes that the emotional shade of the tone of speech is created by the complex mutual influence of the main tone frequency, dynamics and time characteristics (Golovin, 1965).

The use of spontaneous dialogue materials, which are selected basing on the thematic factor (texts on different topics are chosen) in this research can be explained by the fact that an important part of any person's communication activities is made by oral communication, which is unprepared by form and is created at the moment of speech.

Another condition for inclusion of spontaneous dialogues into the experiment materials is that in the oral communicative act, the intonation component becomes an important part of information and acts not as a postsyntactic factor, but as a textual-(discursive) and meaning-forming means.

The functional burden of intonation, is completely, manifested in the spontaneous creation of utterances.

Veysalli describes intonation as "a phonological means which is a suprasegmental phenomenon and plays an important role in conveying ideas to the listener" (Veysalli, 2005), and "from a functional point of view, intonation expresses the question, a relatively completed expression, or its incompleteness in a form of a whole of a thought. We call it an extrinsic function" (Veysalli, 2011). So, ... "since the second function of the intonation serves to carry out the inner parsing of a sentences, we call it the intrinsic function of the sentence" (Veysalli, 2013).

A review of studies on the functional aspect of intonation can be summarized as follows:

a) the parsing of speech flow by means of integration of its segments into different phonetic units and the provision of information about their boundaries;

b) the differentiation of the main elements in phonetic units;

c) the defining of their hierarchy in higher level units.

In explaining the acoustic results from experimental-phonetic analysis of the intonation properties of the language material, we will try to refer to the theoretical provisions that we have mentioned.

In the research, the utterances created from prosodic point of view and uttered by the dialogue participants were taken as the main analytical unit while performing the communicative role of the speaker. In the prosodic organization of the utterances a communicative type, variability caused by individual and situational context was registered.

The average tone frequency in the research was calculated basing on summing the maximum and minimum values of the main tone and dividing the score into two. 


\section{$\mathrm{F}_{0} \max +\mathrm{F}_{0} \min$}

During the analysis of acoustic parameters, the relevant areas for intonation information-frequency level of the utterance beginning, frequency level at the end of the utterance, and finally, indicators of the syllables with utterance stress have been defined.

The most important universal parameter of the main tone frequency is the movement of the tone in the syntagmas. According to the results of the acoustic parameters, it becomes evident that the utterances (syntagms - L. G.) show different intonation contours, depending on their communicative type, destination, the number of syntagms and their location within the utterances - pre, post and middle positions.

Table 2. Change in the main tone frequency within the utterance

\begin{tabular}{lll}
\hline Change of the main tone frequency & Announcer 1 & Announcer 2 \\
\hline rising & 29 & 27 \\
falling & 88 & 91 \\
persistent tone & 18 & 17 \\
\hline
\end{tabular}

Table 3. Change in intensity indicators within the utterance

\begin{tabular}{lll}
\hline Change in intensity & Announcer 1 & Announcer 2 \\
\hline rising & 30 & 27 \\
falling & 84 & 89 \\
coherence (straight) & 21 & 19 \\
\hline
\end{tabular}

Table 4. Change in time indicators within the utterance

\begin{tabular}{lll}
\hline Change of time indicators & Announcer 1 & Announcer 2 \\
\hline rising & 91 & 96 \\
falling & 34 & 33 \\
equal time & 10 & 6 \\
\hline
\end{tabular}

The following indicators were obtained in the analyzed dialogue texts as a result of rising-falling-continuous comparison of the main tone frequencies in accordance with the implementation of the intonation contours in the syntagms. In general, in sintagms $66 \%$ of falling, $21 \%$ of rising and $13 \%$ of continuous intonation contour was recorded (see Table 2; Figure 5).

The analysis of the acoustic results obtained shows that the maximum melodicity was recorded in most cases with $66 \%$ in the initial (progredient) syntagms. In $21 \%$ of the total percentage of investigated syntagmas falling tone was recorded, but in $13 \%$ of them an equal tone contour was recorded (see Table 2; Figure 5).

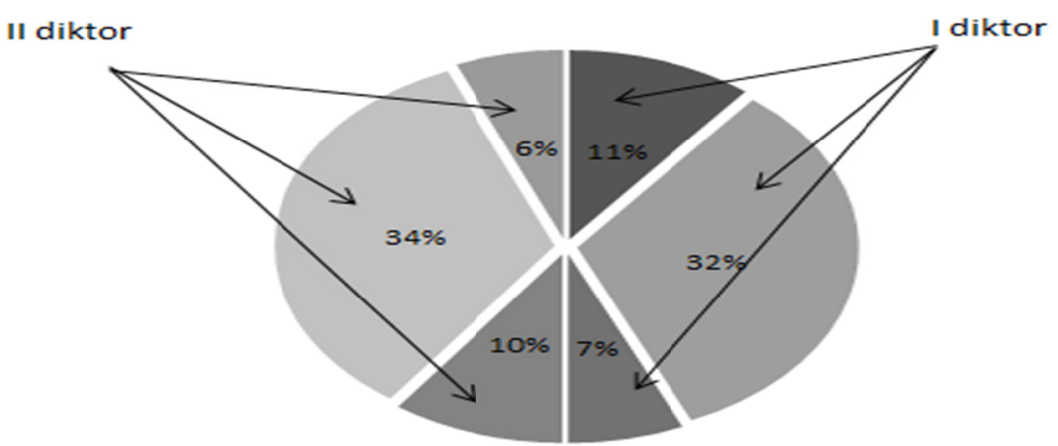

Figure 5. Indicators of average tone frequency of text syntagms (\%)

Note. announcer II, announcer I. 
The following dynamics ratio was obtained in the analyzed dialogue texts, as a result of rising-falling-equal dynamics comparison in the syntagms inside the utterance. In general, $64 \%$ of the analyzed syntagms falling, $21 \%$ rising and in $15 \%$, the same dynamic outline was recorded (see Table 3; Figure 6).

The falling direction of intensity in the terminal syntagma is the acoustic characteristics of its dynamic structure. According to acoustic results of syntagms, towards the end of the sentences the weakening of the intensity in the terminal syntagms is a relevant feature.

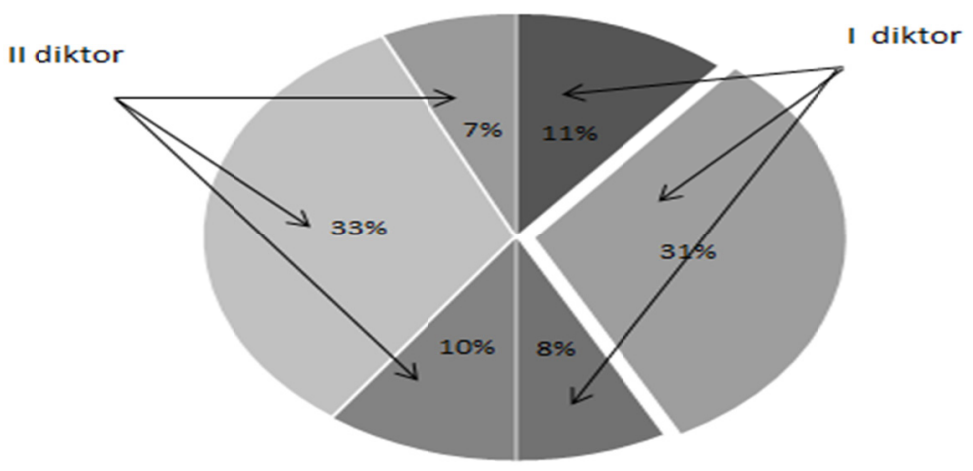

Figure 6. Text intensity indicators on syntagms (\%)

Note. announcer II, announcer I.

In the analyzed dialogue texts, the following proportions were obtained in the case of increasing, decreasing, and equal time values in the investigations.

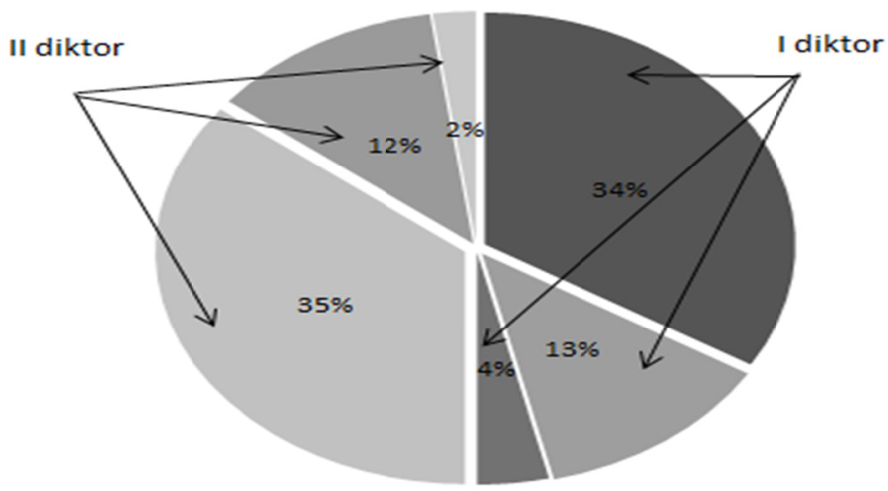

Figure 7. Time indicators of the text on syntagms (\%)

Note. announcer II, announcer I.

In total, in $69 \%$ of syntagms rising, in $25 \%$ of syntagms falling, and in $6 \%$ of syntagms equal time indicators were recorded (see Table 4; Figure 7). As the results show, in the analyzed syntagms, the maximum length is most often localized in approximately $69 \%$ of syntagms in the terminal syntagms, which is a stressed syllable from the point of view of rhythm. Only in $25 \%$ of syntagms falling and in $6 \%$ of syntagms equal time indicators are recorded (see Table 4; Figure 7).

\section{Conclusion}

The experiment proved the dominant role of intonation in the perception of voice text. In the texts in the identification of the author's intention recipients often refer to the intonation of the informant (the speaker who reads the text). The recipient's reaction also is determined by the intonation of the informant. The experimental-phonetic research proved that the parsing into syntagms is the main means of the expression of the common pragmatic direction of suprasentential units in English.

As it is evident from the experiment, acoustic indicators of the common pragmatic direction of the text is realized in the syntagms. In other words, the means of intonation of the syntagm are the main means of expressing the 
illocutive effects of the text.

In English a suprasentential unites complex structural-semantic unit, which not simply the grouping of the independent sentences possessing communicative importance. A sentence "melts" inside the "suprasentential units", in case there is not a deictic element, they lose their independence. In English, the formal features of suprasentential units include a closed syntactic structure, the syntactic independence in a context, a discrete character among sentences in a complex syntactical whole, heterogenous character of the complex syntactical elements of etc.

In the research the analysis of acoustic parameters has identified the indicators. Subdivision of suprasentential sentences involves two or more sentences, conveying the meaning in the context of communication. It has a complex structure that acts as a part considered as a whole. In English, the subdivisions are a complex structural-semantic unit that is not the result of mere collection of independent sentences within the communicative significance. The sentence melts in the subdivision and loses its independence when there is no dexterous element. In English formal signs of a subdivision include closed syntactic structure, the syntactic independence in the context, the interrupted nature of the sentences in the complex syntactic whole, the complex syntactic whole composition, and so on.

In the analysis of the acoustic parameters in the research the followings as relevant spheres for intonation characteristics have been defined: the frequency level of the beginning of the utterance, the frequency level at the end of the utterance in English and the indicators of the syllable which carries the stress of the utterance. Referring to the acoustic results, it should be noted that the English pronunciation have different intonation contours, depending on the communicative type, the purpose, the number of syntagmas, and their location within the sentence - pre, post and middle position, subjective attitude of the speaker.

\section{Reference}

Abdullayev, K. M. (1999). Theoretical Problems of the Syntax of the Azerbaijani language (p. 281). Baku, Maarif.

Brizgunova, E.A. (1993). The answers to the anquet "On the basis of the intonation theory". Problems of Phonetics (vol. 2, pp. 61-66). Moscow. Prosveschenie.

Bulakhovskiy, L. A. (1952). The course of russian literary language (p. 445). Kiev. Radyan school.

Cheremisina, N. V. (1989). Russian intonation: poetry, prose, spoken language (p. 240). Moscow, Russian language.

Retrieved

from

http://www.alib.ru/5_cheremisina_n_v_russkaya_intonaciya_poqziya_proza_razgovornaya_rechnmn_w1t2 $518 \mathrm{ab} 1537 \mathrm{~b} 9 \mathrm{a} 458 \mathrm{a} 585 \mathrm{~d} 8 \mathrm{c} 121 \mathrm{af} 88 \mathrm{c} 22 \mathrm{cee}$

Glison, G. (1959). Introduction to descriptive linguistics (p. 485). Moscow. LKI-press. Retrieved from https://www.studmed.ru/glison-genri-allan-vvedenie-v-deskriptivnuyu-lingvistiku-1959_89b605565b1.html

Golovin, B. N. (1965). From the series of lectures on linguistic statistic (p. 96). Qorkiy.

James, C. (1947). English Contrastive Analysis and its relevance to language teaching (pp. 57-63). University of Michigan. Retrieved from https://www.researchgate.net/publication/271304211_Contrastive_analysis_and_its_relevance_to_language _teaching

Mammadov, A. (2003). The system of formal connection means in the formation of the text (p. 54). Auto-Abstract of the dissertation of doctor of philological sciences. Baku.

Mostalskaya, O. I. (1981). Grammar of the text (aid on the grammar of German for the universities and faculties of foreign languages (p. 183). Moscow, Visshaya Shkola. Retrieved from https://www.studmed.ru/moskalskaya-oi-grammatika-teksta_68c9a447b73.html

Nikolayeva, T. M. (1969). Intonation of compound sentences in Slavic languages (p. 284). Moscow, Prosveschenie. Retrieved from https://inslav.ru/publication/nikolaeva-t-m-intonaciya-slozhnogo-predlozheniya-v-slavyanskih-yazyka-h-op yt

Pierce, Ch. S. (2000). Some consequences of four inabilities (pp. 10-50). The beginning of Pragmatism. S-Pb. Laboratory of metaphysical investigation of Philosophy faculty of S-Pb.SU. Aletey. Retrieved from https://platona.net/load/knigi_po_filosofii/logika/pirs_nachala_pragmatizma_tom_1/18-1-0-4794

Pospelov, N. S. (1948). The problem of complex syntactical whole in Modern Russian. Scientific Notes, 137(2), 
$58-69$.

Potapova, R. K. (1981). Segmental-structural organization of speech (Experimental-phonetic investigation) (p. 50). Auto-Abstract of the dissertation of doctor of philological sciences. Leningrad.

Reformatskiy, A. A. (1955). Introduction to Linguistics (p. 536). Moscow, Prosveschenie. Retrieved from http://www.bsu.ru/content/page/1415/hecadem/reformatsky_aa/reformatsky.pdf

Scherba, L. V. (1974). Language system and speech activity/under the edit. In L. P. Zinder (Ed.), Leningrad (p. 427). Retrieved from http://elib.gnpbu.ru/text/scherba_yazykovaya-sistema--deyatelnost_1974/

Vall, M. N. et al. (1984). Problems of Typology and Contrastive description of Languages (p. 267). Novosibirsk: Nauka. Retrieved from https://rusneb.ru/catalog/010003_000061_1790cf3ba48db79621ab7619c7f9697b/

Veysalli, F. Y. (2005). Basis of Structural Linguistics (vol. 1, P. 344). Baku.

Veysalli, F. Y. (2011). Introduction to German Linguistics (p. 405). Baku. Mutarjim.

Veysalli, F. Y. (2013). Basis of Linguistics. In Studia Philologica (p. 420). Baku. Mutarjim.

Zinder, L. P. (1981). Real flow of speech and "reconstruction" of phoneme component of words (pp. 102-106). Language theory. Methods of its investigation and teaching. collection of articles on the 100-years anniversary of L. B. Shcherba. Nauka. Leningrad branch.

Zinder, L. R., \& Stroley, T. B. (1957). Modern German language (p. 420). Moscow. Literature in foreign languages. Press.

Zolotova, G. A. (1984). On the matter of constituent units of the text. In Functioning of Grammatical categories, Text and context (pp. 167-170). Moscow.

\section{Copyrights}

Copyright for this article is retained by the author, with first publication rights granted to the journal.

This is an open-access article distributed under the terms and conditions of the Creative Commons Attribution license (http://creativecommons.org/licenses/by/4.0/). 